Indonesian Journal of Health Science

Volume 1 No. 2, Desember 2021

\title{
PERAN MATRIKS METALLOPROTEINASE 8 PADA METASTASIS SEL KANKER PAYUDARA
}

\author{
Mike Permata Sari \\ Mikepermatasari1411@gmail.com,Politeknik Kesehatan Hermina
}

\begin{abstract}
MMP-8 is a protease produced by neutrophils and plays a role in the degradation of collagen found in connective tissue in mammals. In humans, the MMP-8 protein is encoded by the MMP-8 gene. In general, MMPs are secreted in the form of proproteins that are activated when cleaved by extracellular proteinases. MMP-8 Ekspression increased in breast cancer patients at different stages, but it is not happenin normal breast cells. MMP-8 has a different substrate with MMP-2 and MMP-9 which play a direct role in causing breast cancer cell metastasis to other organs. The role of MMP-8 in breast cancer has been reported by previous studies that MMP-8 is able to trigger breast cancer metastasis through an increase in proinflammatory cytokines, such as IL-6 and IL-8. IL-6 and IL-8 induce metastasis through the JAK/STAT3 signaling pathway which will activate snail/slug/twist which will suppress E-cadherin expression, in addition IL-6 and IL-8 trigger VEGF synthesis, resulting in the formation of new blood vessels.
\end{abstract}

Keywords : Breast Cancer, Matrix Metalloproteinase-8, Metastasis.

\begin{abstract}
Abstrak
MMP-8 merupakan protease yang diproduksi oleh neutrofil dan berperan dalam degradasi kolagen yang terdapat pada jaringan ikat pada mamalia. Pada manusia, protein MMP-8 disandi oleh gen MMP-8. Pada umumnya, MMP disekresi dalam bentuk proprotein yang diaktifkan ketika dipecah oleh proteinase ekstraseluler. Peningkatan Ekspresi MMP-8 berlebih pada penderita kanker payudara di fase yang berbeda, peningkatan ekspresi MMP-8 tidak ditemukan pada sel payudara normal. MMP-8 memiliki substrat yang berbeda dengan MMP-2 dan MMP-9 yang berperan langsung dalam penyebab metastasis sel kanker payudara ke organ lain. Peran MMP-8 terhadap kanker payudara telah dilaporkan oleh penelitian sebelumnya bahwa MMP-8 mampu memicu metastasis kanker payudara melalui peningkatan sitokin proinflamasi yaitu IL-6 dan IL-8. IL-6 dan IL-8 menginduksi metastasis melalui jalur persinyalan JAK/STAT3 yang akan mengaktifkan snail/slug/twist yang akan menekan ekspresi E-cadherin, selain itu IL-6 dan IL-8 memicu sintesis VEGF sehingga mengakibatkan pembentukan pembuluh darah baru.
\end{abstract}

Kata kunci : Kanker Payudara, Matriks metalloproteinase 8, Metastasis

\section{PENDAHULUAN}

Matriks Metalloproteinase 8 (MMP-8) merupakan enzim protease yang diproduksi oleh neutrofil dan berperan dalam degradasi kolagen (Gutiérrez-Fernández et al., 2008) yang terdapat pada jaringan ikat dari kebanyakan mamalia (FITRIANA, 2013). Pada manusia, protein MMP-8 disandi oleh gen MMP-8. Pada umumnya, MMP disekresi dalam bentuk proprotein yang diaktifkan ketika dipecah oleh proteinase ekstraseluler. Akan tetapi, enzim ini disimpan di granuler sekunder dari netrofil yang diaktivasi dengan cara pemecahan autolitik. Fungsinya adalah untuk mendegradasi kolagen jenis I, II, dan III (FITRIANA, 2013).

Kanker payudara merupakan salah satu penyakit yang menjadi penyebab kematian yang utama di dunia. Peran MMP-8 terhadap kanker payudara telah dilaporkan oleh penelitian sebelumnya bahwa MMP-8 mampu memicu metastasis kanker payudara melalui peningkatan sitokin proinflamasi yaitu interleukin 6 (IL-6) dan interleukin 8 (IL-8) yang dapat menginduksi terbentuk angiogenesis yang menyebabkan angiogenesis. Tujuan penelitian ini membahas mengenai peran MMP-8 dalam metastasis sel kanker payudara. 


\section{Indonesian Journal of Health Science}

Volume 1 No. 2, Desember 2021

\section{METODE}

Pembahasan melakukan penulusuran artikel terkait peran MMP-8 terhadap kanker payudara baik yang bermetastasis atau tidak bermetastasis.

\section{HASIL DAN PEMBAHASAN \\ Matriks Metalloproteinase 8 (MMP-8)}

Matriks Metallporoteinase 8 (MMP-8) merupakan salah satu enzim protease jenis kolagenase yaitu kolagenase-2 atau kolagenase neutrofil karena dapat mendegradasi kolagen tipe I, II dan III. MMP-8 diekspresikan oleh banyak sel seperti sel ephitelial, fibroblast, sel endothelial, makrofag dan neutrofil (Decock et al., 2015). MMP-8 dikode oleh 467 asam amino dengan sekuens sinyal sekretori sebanyak 20 residu dan predomain sebanyak 80 residu dan menempati lokasi 11q22 pada kromosom (Hu et al., 1999). Struktur MMP-8 secara garis besar terdiri dari; 1. sinyal peptide adalah sinyal yang mengatur MMP ntuk disekresikan oleh sel yang memproduksinya, 2. prodomain berperan untuk menjaga situs aktif enzim dalam keadaan tidak aktif dengan cara menempati situs aktif zink dan membuat situs katalitik enzim tidak dapat diakses oleh substrat, 3. zink yang menempati situs katalitik enzim bertujuan untuk menjaga proMMP dalam keadaan tidak aktif, 4. Domain hemopexin yang memediasi interaksi dengan substrat dan memberi spesifisitas enzim, 5. Hinge region yang menghubungkan situs katalitik dan domain homopexin. Pengaktifan proMMP8 menjadi MMP-8 aktif dengan cara menghilangkan signal peptide, membebaskan situs katalitik dari ion zinc, dan terjadi pelipatan proses pelipatan protein. (Vargova, Pytliak, \& Mechirova, 2012) (gambar 1) dan struktur tiga dimensi pada (gambar 2).

\section{Gambar 1. Struktur MMP-8}

MMP1, $-3,-8$,

$-10,-12,-13,-18$ $-19,-20,-22,-27$ ColA, ColB

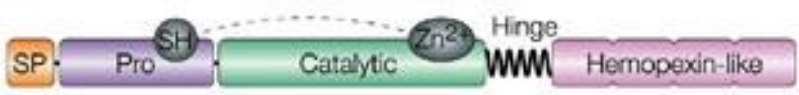

Sumber : (Cathcart, Pulkoski-Gross, \& Cao, 2015)

Gambar 2. Struktur tiga dimensi MMP-8

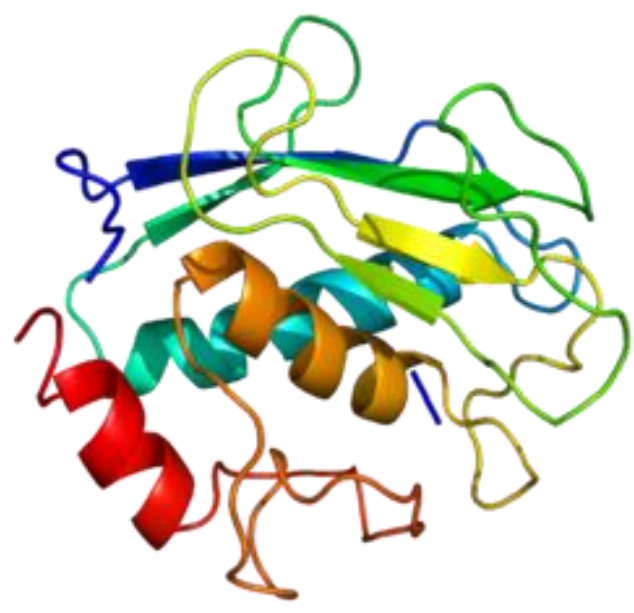

Sumber : (Cathcart et al., 2015) 


\section{Indonesian Journal of Health Science}

Volume 1 No. 2, Desember 2021

MMP-8 berperan dalam pelilisan matriks ekstraseluler untuk remodeling jaringan dan perbaikan sel dengan medegradasi serat kolagen. MMP-8 yang memotong serat kolagen tipe I lebih efisien dari pada memotong kolagen tipe II dan III. MMP-8 dapat memotong serat di lokasi tertentu yaitu 3/4 dari ujung $\mathrm{N}$-terminus sehingga menghasilkan peptide $\mathrm{N}$-terminus $3 / 4$ dan peptide $\mathrm{C}$ terminus sepanjang 4 inchi. Ekspresi MMP-8 yang berlebih dapat menyebabkan kerusakan kolagen dan meningkatkan respon inflamasi. MMP-8 juga terlibat dalam perkembangan kanker, namun temuan terbaru menunjukkan bahwa MMP-8 pada tahap awal kanker dapat mengurangi pembentukan dan penyebaran tumor (Schlemmer, 2016).

\section{Peran MMP-8 Pada Kanker Payudara}

Kanker payudara merupakan salah satu penyakit tidak menular yang disebabkan oleh sekelompok sel yang tumbuh secara tidak normal pada jaringan payudara. Kanker payudara yang telah mengalami invasif dan metastasis adalah sel kanker yang telah menyebar dari saluran payudara atau lobulus ke jaringan normal disekitarnya (National Cancer Institue, 2012).

MMP-8 dikenal sebagai enzim protease ekstraseluler yang memiliki peran sebagai pemicu aktifnya respon imun proinflamasi sehingga menyebabkan sel kanker payudara mengalami metastasis. Peran tersebut dipengaruhi oleh keadaan atau kondisi sel kanker payudara tersebut.

Pada jaringan payudara manusia normal dan pada tumor payudara jinak akan mengekspresikan MMP-8 dalam jumlah normal namun, ekspresi MMP-8 yang berlebih ditemui pada sel stroma kanker payudara. Peningkatan ekspresi MMP-8 ini sangat tergantung dari grade tumor payudara itu sendiri. Menurut penelitian yang menggunakan sampel wanita yang mengidap kanker grade II dan III dan tidak pernah mendapatkan penanganan seperti kemoterapi atau radioterapi lalu sebagai kontrol adalah wanita yang mempunyai sel payudara normal, penelitian ini menyatakan bahwa MMP-8 diekspresikan berlebih pada grade III namun sudah mulai meningkat dari grade II (gambar 3) (Benson, Babu, Radhakrishna, Selvamurugan, \& Sankar, 2013). Peningkatan ekspresi MMP-8 ini sangat mempengaruhi peran MMP-8 dalam invasif dan metastasis.

\section{Gambar 3. Ekspresi MMP-8 pada kanker payudara grade II dan II.}

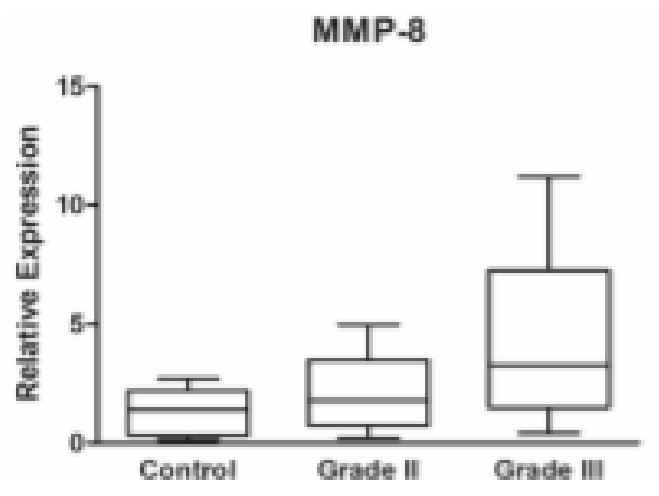

Sumber : (Benson et al., 2013)

Dari gambar di atas diketahui adanya peningkatan jumlah MMP-8 pada grade II dan III dan tidak terjadi peningkatan pada kontrol. Pada kanker payudara, MMP-8 tidak berperan langsung dalam mencetus metastasis hal ini disebabkan karena MMP-8 tidak mendegradasi substrat yang sama seperti MMP-2 dan MMP-9 sehingga tidak berperan langsung dalam metastasis sel kanker payudara (Schlemmer, 2016). MMP-2 dan MMP-9 mendegradasi kolagen tipe IV pada ECM yang 


\section{Indonesian Journal of Health Science}

Volume 1 No. 2, Desember 2021

berhubungan langsung antara sel dengan ECM sehingga sangat memediasi proses metastasis kanker payudara disebabkan karena MMP-2 dan MMP-9 memiliki struktur collagen binding domain (CBD) atau yang disebut pelekatan gelatinase pada kolagen yang disebut fibronectin-II like domain (Monaco et al., 2006). MMP-2 dan MMP-9 ini yang dijadikan pencetus angiogenesis, pertumbuhan kanker dan motilitas sel kanker karena Selama mendegradasi kolagen tipe IV enzim ini akan melepaskan VEGF (Vascular endothelial growth factor) dan mengakibatkan migrasi dan proliferasi sel endhotelial untuk menciptakan pembuluh darah baru.

Kondisi berbeda jika sel kanker payudara telah mengalami metastasis, MMP-8 akan berperan dalam peningkatan sitokin proinflamasi yaitu interleukin 6 (IL-6) dan interleukin 8 (IL8) yang dapat menginduksi metastasis sel kanker. IL-8 dan IL-6 menginduksi metastasis melalui jalur persinyalan JAK/STAT3 yang akan mengaktifkan snail/slug/twist yang akan menekan ekspresi E-cadherin, spade jalur lain. Ikatan antara IL-8 dan reseptornya akan memicu penekanan ekspresi E-chaderin melalui pengaktifan faktor transkripsi Brachyury di T-Box. Selain itu, IL-6 dan IL-8 dapat memicu sintesis VEGF sehingga mengakibatkan pembentukan pembuluh darah baru.

Peran MMP-8 sebagai pencetus peningkatan sitokin pro-inflamasi telah dibuktikan oleh penelitian yang menggunakan 3 jenis mencit model MMTV-PyMT (mause mammart tumor virusPolyoma virus middle T-antigen) yaitu MMTV-PyMT ; MMP-8 Wild type (WT), MMTV-PyMT ; MMP-8 Heterozigot (HT) dan MMTV-PyMT ; MMP-8 Null (KO), ketiga jenis mencit ini berumur 6 minggu dan telah menderita kanker payudara yang diinduksi oleh virus polyoma dan telah memperlihatkan metastasis sel kanker payudara pada paru-paru dan kelenjar getah bening. Setelah dilakukan pemeriksaan menggunakan imunohistokimia terjadi peningkatan makrofag dan inflitrasi neutrofil, kemudian setelah dilakukan RNA profiling menggunakan CD68, menyatakan bahwa adanya ekspresi mediator interleukin 6 (IL-6) dan reseptor murine interleukin 8 (IL-8) CXCL-5/LIX dari mencit berumur 6 minggu sampai 14 minggu (gambar 6). Dari penelitian tersebut dapat dijelaskan bahwa IL-6 meningkat pada mencit umur 10 minggu dan mengalami penurunan pada umur 14 minggu, IL-8 mengalami peningkatan pada umur 14 minggu (Decock et al., 2015). Dari pernyataan ini dapat disimpulkan bahwa peningkatan IL-6 dan IL-8 oleh MMP-8 dapat menjadi penanda bahwa sel kanker telah mengalami metastasis dan memediasi angiogenesis.

\section{PENUTUP}

\section{Simpulan}

MMP disekresi dalam bentuk proprotein yang diaktifkan ketika dipecah oleh proteinase ekstraseluler. MMP-8 dikenal sebagai enzim protease ekstraseluler yang memiliki peran sebagai pemicu aktifnya respon imun proinflamasi sehingga menyebabkan sel kanker payudara mengalami metastasis. Peningkatan ekspresi MMP-8 terjadi pada peningkatan fase pertumbuhan sel kanker. Peningkatan MMP-8 pada sel kanker yang telah mengalami metastasis akan memicu peningkatan sitokinin proinflamasi yang menyebabkan penekanan ekspresi E-Chaderin dan angiogenesis sehingga semakin memicu terjadi penyebaran sel kanker payudara ke organ lain.

\section{DAFTAR PUSTAKA}

Benson, C. S., Babu, S. D., Radhakrishna, S., Selvamurugan, N., \& Sankar, B. R. (2013). Expression of matrix metalloproteinases in human breast cancer tissues. Disease Markers, 34(6), 395-405. https://doi.org/10.3233/DMA-130986

Cathcart, J., Pulkoski-Gross, A., \& Cao, J. (2015). Targeting matrix metalloproteinases in cancer: 


\section{Indonesian Journal of Health Science}

Volume 1 No. 2, Desember 2021

Bringing new life to old ideas. Genes and Diseases, 2(1), 26-34. https://doi.org/10.1016/j.gendis.2014.12.002

Decock, J., Hendrickx, W., Thirkettle, S., Gutiérrez-Fernández, A., Robinson, S. D., \& Edwards, D. R. (2015). Pleiotropic functions of the tumor- and metastasis-suppressing matrix metalloproteinase-8 in mammary cancer in MMTV-PyMT transgenic mice. Breast Cancer Research : BCR, 17, 38. https://doi.org/10.1186/s13058-015-0545-8

Fitriana, A. (2013). Perbedaan kadar matriks metalloproteinase 8 cairan sulkus gingiva pada pemakaian alat ostodonti cekat yang bertujuan terapi dan aksesoris.

Gutiérrez-Fernández, A., Fueyo, A., Folgueras, A. R., Garabaya, C., Pennington, C. J., Pilgrim, S., ... López-Otín, C. (2008). Matrix metalloproteinase-8 functions as a metastasis suppressor through modulation of tumor cell adhesion and invasion. Cancer Research, 68(8), 2755-2763. https://doi.org/10.1158/0008-5472.CAN-07-5154

Hu, S. I., Klein, M., Carozza, M., Rediske, J., Peppard, J., \& Qi, J. S. (1999). Identification of a splice variant of neutrophil collagenase (MMP-8). FEBS Letters, 443(1), 8-10. https://doi.org/10.1016/S0014-5793(98)01654-8

Monaco, S., Sparano, V., Gioia, M., Sbardella, D., Di Pierro, D., Marini, S., \& Coletta, M. (2006). Enzymatic processing of collagen IV by MMP-2 (gelatinase A) affects neutrophil migration and it is modulated by extracatalytic domains. Protein Science, 15(12), 2805-2815. https://doi.org/10.1110/ps.062430706

National Cancer Institue. (2012). What You Need to Know About Breast Cancer, 1-46.

Schlemmer, A. M. (2016). Characterization of Matrix Metalloproteinase-8 (MMP-8) Structure and Stability and the Effects of Its Interaction with the Inhibitory Metal Abstraction Peptide NCC Using High-Resolution Solution NMR By. University of Kansas.

Vargova, V., Pytliak, M., \& Mechirova, V. (2012). Matrix metalloproteinase inhibitors: Specificity of Binding and Structure-Activity relationships. https://doi.org/10.1007/978-3-0348-0364-9 